\title{
Enhancement the Shear behavior of concrete beams reinforced with hybrid-wires bars by using steel fibers.
}

\author{
Mohamed. Zakaria ${ }^{1, ~ *}$, Donia. Salah. Ali ${ }^{2},{ }^{*}$, Mohamed.M.A. Ismael ${ }^{3, *}$, Zakaria. H. Awadallah ${ }^{4}$ \\ ${ }^{1}$ Prof. Dr of Civil Eng. Dept., Faculty of Eng. Aswan University, Aswan, Egypt. \\ ${ }^{2}$ Ass. Prof. Dr of Civil Eng.Dept., Faculty of Eng. Al-Azhar University, Dena, Egypt. \\ ${ }^{3} B$. Sc., Civil Engineering, south valley University, Qena, Egypt. \\ ${ }^{4}$ Ass. Prof. Dr of Civil Eng. Dept., Faculty of Eng. Assiut University, Assiut, Egypt.
}

\section{ABSTRACT}

This research studies the shear behavior of concrete beams reinforced with hybrid-wires FRP bars with minimum stirrups. Eight shear beams were tested under a four-point static load up to failure. The beams were divided into three groups according to different parameters: the type of main reinforcement (steel bars, glass fiber reinforcement bars and hybrid wires bars), the ratio between the area of steel wires to the total area of the main reinforcement bar, which consists of steel wires and GFRP (25\%steel wires, $50 \%$ steel wires and $75 \%$ steel wires) and the steel fibers volumetric ratio $(0.4 \%, 0.8 \%$ and $1.2 \%)$. The experimental study shows that using hybrid wires bars as main reinforcement to overcome low modulus of elasticity of FRP bars leads to improve cracking, ultimate shear strength and ductility of the tested beams, and transfers the mode of failure of these beams into a more ductile than FRP beams. It is important to note that; increasing the ratio of steel wires to the total area of the main reinforcement bar from $25 \%$ to $75 \%$ leads to increase the ultimate shear capacity by approximately $64 \%$. A high value of shear strength is obtained when the ratio is increased to reach $75 \%$, and it can be used as main reinforcement instead of steel reinforcement. Furthermore, increasing the steel fiber content from zero to $1.2 \%$ volume fraction produces an increase in shear capacity and improves the mode of failure.

Keywords: Hybrid-wires bars, Shear strength, Deflection and Ductility of beams.

\section{abbreviation}

$A_{\text {Steel }}=$ Area of steel wires in hybrid reinforcement bar . $A_{\text {Total }}=$ Area of total hybrid reinforcement bar .

$F R P=$ Fiber-Reinforced Polymer.

$G F R P=$ glass fiber reinforced polymer.

$C F R P=$ carbon fiber reinforced polymer .

$A F R P=$ Aramid fiber reinforced polymer.

$F R C=$ fiber-reinforced concrete.

$V_{f} \%=$ The steel fibers volumetric ratio

C.R.L. $=($ Concrete Research Laboratory) at Assiut University.

$E_{\text {hybird }}=$ modulus of elasticity of hybrid wires bars.

$A_{\text {hybird }}=$ Area of hybrid wires reinforcement bar

$p_{1}=$ the applied loads corresponding to 50\%. of the ultimate load,

$p_{2}=$ the applied loads corresponding to $25 \%$. of the ultimate load

$\varepsilon_{1}=$ the strain due to applied loads corresponding to $50 \%$. of the ultimate load.

$\varepsilon_{2}=$ the strain due to applied loads corresponding to $50 \%$. of the ultimate load.

$f c u=$ cube concrete compressive
strength.

$F c^{\prime}=$ Cylindricalconcrete compressive strength.

$a / d=$ Shear span to depth ratio.

$L / d=$ Aspect ratio

$f s=$ Steel tensile stress .

$f y=$ yield steel stress

$\varepsilon_{s}=$ tensile steel strain.

$f u=$ ultimate tensile stress.

pcr $=$ flexural cracking load .

$p_{u}=$ ultimate load .

$V_{C r}=$ crack shearing load.

$V_{U}=$ ultimate shearing load.

$\Delta_{\text {max }}=$ maximum deflection .

$\Delta_{C r}=$ deflection at crack shearing load.

$\mu_{D}=$ the displacement ductility index. 


\section{INTRODUCTION}

The main challenge for civil engineers is to provide sustainable, eco-friendly and economical building materials. Therefore, new building materials must be found to fulfill these requirements.

Recently, advanced composite materials have been applied to mitigate the problem of corrosion in reinforced concrete structures. Fiber-Reinforced Polymer (FRP) bars are one form of these composites which are used as a flexural reinforcing bar in reinforced concrete beams. Three common types of FRP bars are used as a main reinforcement (GFRP, CFRP, and AFRP) bars. The advantages of using these bars are (high tensile strength, resistant to corrosion, nonmagnetic, high fatigue endurance and their low weight) compared to steel. Most types of FRP have a low elastic modulus compared to steel bars. Hybrid-wires Reinforced Polymer bars (GFRP, steel wires and resin with different ratios in the same bar) are the newest types of hybridization bars which have some advantages than others as lower life cycle cost, high modulus of elasticity compared to FRP and high resistance to corrosion.

Due to the relatively low modulus of elasticity of FRP bars, the concrete beams which are reinforced longitudinally with FRP bars will result wider and deeper cracks than those reinforced with steel bars. Deeper cracks reduce the shear strength from the uncracked concrete due to the lower depth of concrete in compression because the neutral axis shifted up. Wider cracks reduce the aggregate interlock and residual tensile stresses. And, due to the

Received:29October, 2020, Accepted: 8November, 2020 small transverse force of FRP rods and wider cracks the dowel action may be ignored. So, the shear capacity of concrete beams reinforced with FRP bars is less than beams reinforced with steel bars [1].

Concept of combining steel bars with FRP bars (hybrid system) in reinforcing concrete structures seems to be a practical solution to overcome the ductility and serviceability problems of purely FRP-reinforced structures. Yong, seo et al. [2] investigated the performance of hybrid GFRP/steel reinforced concrete beams, it was found that the maximum crack width of hybrid beams is mainly controlled by steel bars. Increasing the depth of steel layers led to decrease the maximum crack width. Saikia, et al. [3] studied beams reinforced with Hybrid bars which basically consist of glass fiber reinforced polymer (GFRP) strands of $2 \mathrm{~mm}$ diameter breadth twisted helically on a mild steel core of $6 \mathrm{~mm}$ diameter. $\mathrm{He}$ found that Failure modes observed in shear control beams reinforced with hybrid rebars were similar to steel reinforced beams. However, the shear strength of the beams reinforced with the hybrid rebars was found to be significantly lower than the beam with steel bar as longitudinal reinforcement. Dong-Woo Seo et al [4] suggested two types of hybrid GFRP bars considering: a) steel core surrounded by GFRP; b) GFRP bar with steel wires. Using glass fibers and unsaturated polyester resins to develop the concept of hybridization increases the elastic modulus of GFRP Bar with acceptable tensile strength. Yong, seo et al. [5] made the tensile test of FHB samples as three cases sorted by various 
diameters, equal to $13 \mathrm{~mm}, 16 \mathrm{~mm}$ and $19 \mathrm{~mm}$, it was noticed that the elastic modulus of FRP Hybrid Bar can be increased to approximately 250 percent. The material hybridization with a suitable tensile strength and the stress strain behavior was the "pseudo-ductile" as close as possible to the behavior of steel.

On the other hand, it is necessary to improve the concrete materials to reach the maximum capacity of shear forces. HSC (high strength concrete) is considered as a relatively brittle material and the post-peak portion of its stressstrain diagram almost vanishes and declines sharply with the increase of compressive strength. This converse relation between strength and ductility is a serious obstacle in the use of high strength concrete. a settlement between strength and ductility can be achieved by using discontinuous fibers. Adding fibers to concrete makes it a homogeneous and isotropic material and transforms the brittle into a ductile behavior. At the point, when the concrete beam cracks, the randomly oriented fibers start working, arresting both the randomly oriented micro-cracking and its propagation therefore improving strength and ductility [6].

Many researches published over the past 25 years [7-13] have reflected the possibility of using fiber in reinforced concrete by specifying the functions of shear reinforcement to the fibers. The experimental study has illustrated that the containment of suitable quantities steel fibers in the concrete improved the shear resistance because of the increase in tensile strength, slowing the formation and growth of cracks, smaller distance between the fibers with respect to the distance between stirrups, implying greater effectiveness in the crack arresting mechanism and better redistribution of tensile crack.
Zakaria. H. Awadallah et.al [1] studied the shear behaviour of high strength fiber reinforced concrete beams longitudinally reinforced with Basalt Fiber Reinforced Plastic (BFRP) bars without and with stirrups. The test variables were steel fiber content $\left(V_{f}\right) \%$ without and with minimum shear reinforcement. The experimental study shows that the addition of steel fiber improved cracking, ultimate shear strength and ductility of the tested beams, and transfered the mode of failure of these beams into a more ductile one. Beams with steel fiber and vertical steel stirrups showed more ductility than that with steel fiber only.

Doo-YeolYooa and Jun-MoYang[14], investigated the effectiveness of steel fibers and minimum amount of stirrups on the shear response of various sized reinforced highstrength concrete (HSC) beams. Test results indicated that, with increasing beam size, significantly lower shear strength was obtained for steel fiber-reinforced high-strength concrete (SFR-HSC) beams without stirrups than for the plain HSC beams with stirrups. The inclusion of steel fibers effectively limited crack propagation, produced more diffused initial flexural cracks, and led to higher post-cracking stiffness, compared to plain HSC. On the other hand, the use of minimum stirrups gave better shear cracking behaviors than that of steel fibers, and effectively mitigated the size effect on shear strength. Therefore, a large decrease in shear strength, with an increase in the beam size, was only obtained for SFR-HSC beams without stirrups.

In this paper, useful insights on the shear behavior of high strength fiber reinforced concrete which is reinforced longitudinally with hybrid wires bars will be discussed to achieve improvement in two ways the concrete 
properties and the reinforcement together in shear behavior.

\section{EXPERIMENTAL WORK}

The experimental program consisted of eight beams. Dividing into three groups. In each group, the effect of one variable was taken into consideration while the other parameters were constant.

The following section Detailed description of the specimens, the material properties, test setup, instrumentation, test steps, and measurements are presented.

\subsection{Test Specimens:}

The first group involved testing of two beams with variable type of main reinforcement (steel and GFRP). The second group involved testing of three beams with different ratio of steel wires area $\left(\mathrm{A}_{\text {Steel }}\right)$ to total area $\left(\mathrm{A}_{\text {total }}\right)$ of the bar $\left(\mathrm{A}_{\text {Steel }} /\right.$ $\left.A_{\text {total }}\right)$ as a main reinforcement, while the residual group consisted of three beams with a volume fractions of steel fiber $\left(V_{f} \%\right)$ as $0.4 \%$, $0.8 \%$, and $1.2 \%$ respectively.

In the experimental program, tests were carried out on eight concrete beams with nominal cross-sectional dimensions of $150 \times 250 \mathrm{~mm}$ with a total length of $2400 \mathrm{~mm}$. All tested beams have $1850 \mathrm{~mm}$ clear span. Ribbed hybrid wires rods of $2000 \mathrm{~mm}$ length and $10 \mathrm{~mm}$ diameter were used as a main flexural reinforcement. Mild steel bars of $6 \mathrm{~mm}$ diameter @ 200mm were used as stirrups in order to increase the beam shear strength, which give it longer time to fail and give us a better chance to study its behavior and notice how exactly the cracks spread. On the other hand, using stirrups provide us with a practical simulated example, in addition to that, we use a fixed stirrups ratio in all our beams, to study and compare the other remaining parameters. $8 \mathrm{~mm}$ diameter were used as a compression steel. The beams were simply supported and subjected to two concentrated static loads (four-point bending). All beams were tested at a shear span-to-depth ratio of $(\mathrm{a} / \mathrm{d})=1.5$. The tested beams details were shown in Table (1) and Fig (2).

\subsection{Materials:}

Concrete mix design was made to produce normal strength concrete having 28-day cubic compressive strength $25 \mathrm{MPa}$. Concrete mix properties were given in Table (2). Local natural sand, well-graded gravel with maximum nominal size $20 \mathrm{~mm}$ aggregate. The sieve analysis of coarse aggregate is presented in Table (4). Ordinary Portland cement were used. Crimped Steel fibers with an aspect ratio of 20 were also used. The table (3) showed the properties of the used steel fibers. The compressive strength results from the three cubes tested in the study were presented in table (1). The mechanical properties of hybrid-wires FRP bars with a different ratio of steel wires and the steel bars were shown in Table (5 and 6). Picture (1 and 2) Fig (1) illustrated the cross section of hybrid wires bars with a different ratio. The mixes used to cast the specimens were developed by trial batching in C.R.L. (Concrete Research Laboratory) at Assiut University.

\subsection{Preparing Test Specimens and Test}

\section{Procedure:}

Mixing was performed by using a concrete tilting drum mixer. The time of mixing was about five minutes. Clean wood forms were used, and their inner sides were coated with oil before casting. slowly add steel fibers into the mixer to ensure that the steel fibers are uniformly distributed in the mixture.

Concrete was placed and compacted mechanically by an internal electrical vibrator. After 24 hours, the wood forms were removed and the daily curing was started till the day before testing. All beams were simply supported and tested at 28 days age under four point static load using the available testing machine (EMS 60-Ton). The used supported elements were steel bearing plates having $10 \times$ $20 \times 1.25 \mathrm{~cm}$ dimensions. The first support was roller, while the second was hinged. The applied load was transmitted from the load cell to a steel I-beam plate to make concentrated load in two points instead of one point on the 
tested beam. The mid - span deflection of the tested beam was measured by using dial gage having an accuracy of 0.001 inch. The load was applied in increments of 0.5 ton, and was kept constant between two successive increments for about one minute to allow for reading of the dial gages and marking the crack propagation.

\subsection{Tensile Test Specimens.}

The samples of reinforcement with $550 \mathrm{~mm}$ length were prepared and tested in tension according to (ECP 208-2005) [15]. All specimens were fixed both at the top and the bottom with steel grip of $200 \mathrm{~mm}$ long steel tubes which were filled by an epoxy material. The specimens were kept more than 30 days before testing to allow curing. One strain gauge of $10 \mathrm{~mm}$ length was attached longitudinally at the center of the specimens. The loads were applied to the specimens by a 100 (KN) capacity testing machine. The load was measured by the load cell of the test machine and the slip of bars from tube and elongation for bars were measured by using differential transformers LVDTs and strain gauge respectively. A data loggers system was used to collect the test data automatically. The modulus of elasticity of GFRP specimens and FRP hybrid bars specimens was calculated according to Eq. (1)

$$
E_{\text {hybird }}=\frac{p_{1}-p_{2}}{\varepsilon_{1}-\varepsilon_{2} A_{\text {hybird }}}
$$

In Eq (1) $p_{1}$ and $p_{2}$ are the applied loads corresponding to $50 \%$ and $25 \%$ of the ultimate load, respectively, and $\varepsilon_{1}$ and $\varepsilon_{2}$ are the corresponding strains.

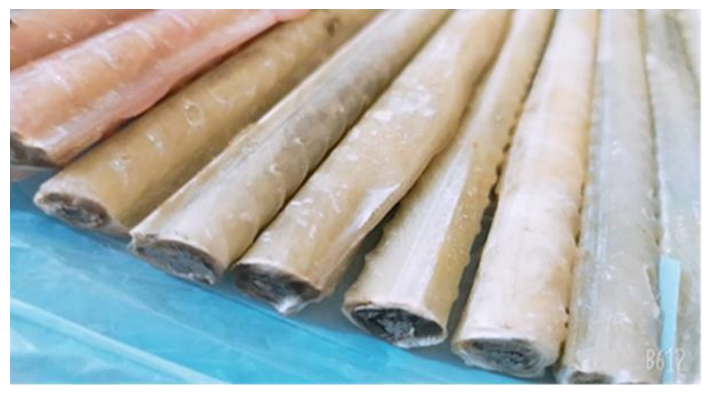

Picture.1. Cross-section view of the FRP Hybrid Bar.

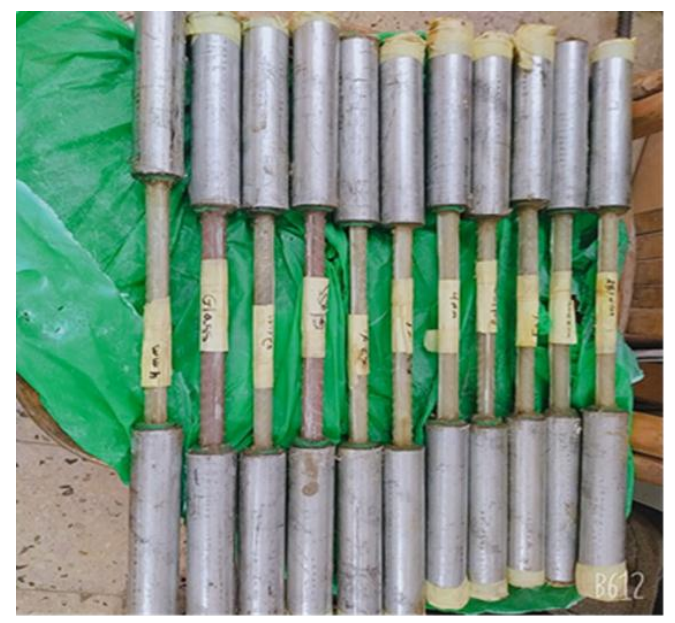

Picture.2. the Hybrid wires Bars during tension test.

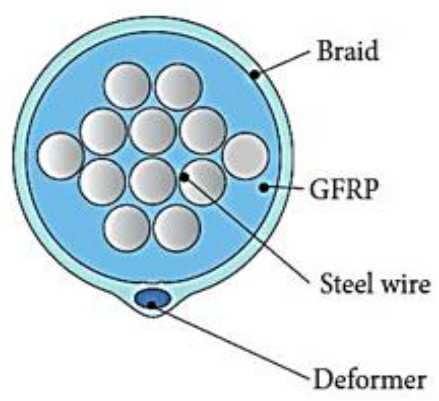

Fig.1. A cross-sectional view of a GFRP bar with steel wires (A hybrid wires bar).

Table 1. The details of tested beams.

\begin{tabular}{|c|c|c|c|c|c|c|c|}
\hline Group & $\begin{array}{c}\text { Beam } \\
\text { No. }\end{array}$ & $\begin{array}{c}\boldsymbol{f}_{c u} \\
(\mathbf{M P a})\end{array}$ & $\begin{array}{c}\boldsymbol{f}_{\boldsymbol{c}} \boldsymbol{(} \\
(\boldsymbol{M P a})\end{array}$ & $\boldsymbol{a} / \boldsymbol{d}$ & $\begin{array}{c}\text { Main Reinforcement } \\
\text { Type }\end{array}$ & $\begin{array}{c}\text { Steel Fiber } \\
\text { Ratio }\left(\boldsymbol{V}_{\boldsymbol{f}} \boldsymbol{\%}\right)\end{array}$ & $\begin{array}{c}\text { Shear } \\
\text { Reinf. }\end{array}$ \\
\hline & D0 & 26.2 & 20.96 & & $2 \varphi 10 \mathrm{~S}$ & - & \\
\hline
\end{tabular}


Vol.41, No. 1. January 2022

\begin{tabular}{|c|c|c|c|c|c|c|c|}
\hline 1 & D1 & 26.2 & 20.96 & \multirow{7}{*}{1.5} & $2 \varphi 10 \mathrm{G}$ & - & \multirow{7}{*}{$\begin{array}{c}\text { Ф6@ } \\
200 \mathrm{~mm}\end{array}$} \\
\hline \multirow{3}{*}{2} & D2 & 26.2 & 20.96 & & $2 \varphi 10(\mathrm{~S} 25 \%, \mathrm{G} 75 \%)$ & - & \\
\hline & D3 & 26.2 & 20.96 & & $2 \varphi 10(\mathrm{~S} 50 \%, \mathrm{G} 50 \%)$ & - & \\
\hline & D4 & 26.2 & 20.96 & & $2 \varphi 10(\mathrm{~S} 75 \%, \mathrm{G} 25 \%)$ & - & \\
\hline \multirow{3}{*}{3} & D5 & 29.4 & 23.52 & & $2 \varphi 10(\mathrm{~S} 75 \%, \mathrm{G} 25 \%)$ & 0.4 & \\
\hline & D6 & 32.7 & 26.16 & & $2 \varphi 10(\mathrm{~S} 75 \%, \mathrm{G} 25 \%)$ & 0.8 & \\
\hline & D7 & 33.1 & 26.48 & & $2 \varphi 10(\mathrm{~S} 75 \%, \mathrm{G} 25 \%)$ & 1.2 & \\
\hline
\end{tabular}

Table 2. Concrete mixture proportions.

\begin{tabular}{|c|c|c|c|c|}
\hline $\begin{array}{c}\text { Cement } \\
\left(\mathbf{K g} / \mathbf{m}^{\mathbf{3}}\right)\end{array}$ & $\begin{array}{c}\text { Sand } \\
\left(\mathbf{K g} / \mathbf{m}^{\mathbf{3}}\right)\end{array}$ & $\begin{array}{c}\text { Agg. (A) } \\
<\mathbf{1 0 m m} \\
\left(\mathbf{K g} / \mathbf{m}^{\mathbf{3}}\right)\end{array}$ & $\begin{array}{c}\text { Agg. (B) } \\
\mathbf{2 0 > 1 0 \mathbf { m m }} \\
\left(\mathbf{K g} / \mathbf{m}^{\mathbf{3}}\right)\end{array}$ & $\begin{array}{c}\text { Water } \\
\left(\mathbf{L i t e r} / \mathbf{m}^{\mathbf{3}}\right)\end{array}$ \\
\hline 454 & 756.2 & 695 & 695 & 231.25 \\
\hline
\end{tabular}

Table 3. Hooked-end steel fiber properties.

\begin{tabular}{|c|c|}
\hline Length $(\mathbf{m m})$ & 20 \\
\hline Diameter $(\mathbf{m m})$ & 1 \\
\hline Aspect ratio $(\mathbf{L} / \mathbf{d})$ & 20 \\
\hline Ultimate Strength $(\mathbf{M P a})$ & 1150 \\
\hline Shape & \\
\hline
\end{tabular}

Table 4. Sieve analysis of gravel.

\begin{tabular}{|c|c|}
\hline Sieve size & \% pass by weight to each sieve of Gravel \\
\hline $\mathbf{4 0} \mathbf{m m}$ & 100 \\
\hline $\mathbf{2 0} \mathbf{m m}$ & 91.82 \\
\hline $\mathbf{1 0} \mathbf{m m}$ & 35.06 \\
\hline $\mathbf{5 m m}$ & 1.01 \\
\hline
\end{tabular}

Table 5. Mechanical properties of the steel bars.

\begin{tabular}{|c|c|c|c|c|}
\hline Reinforcement Type & Area $\left(\mathbf{m m}^{\mathbf{2}}\right)$ & $\boldsymbol{f}_{\boldsymbol{y}} \mathbf{( M P a )}$ & $\boldsymbol{f}_{\boldsymbol{u}} \mathbf{( M P a )}$ & $\mathfrak{f}_{\mathbf{s}}(\boldsymbol{\%})$ \\
\hline 6-mm mild steel bar & 28.26 & 294 & 411 & 29.25 \\
\hline 8-mm mild steel bar & 50.24 & 366 & 426 & 26.6 \\
\hline 10mm-high tensile steel bar & 78.5 & 496 & 655 & 24.8 \\
\hline
\end{tabular}

Table 6. Mechanical properties of the GFRP/Hybrid bars.

\begin{tabular}{|l|c|c|c|c|} 
Reinforcement Type & $\begin{array}{c}\text { Diameter } \\
(\mathbf{m m})\end{array}$ & Area $\left(\mathbf{m m}^{2}\right)$ & $f_{u}(\mathrm{MPa})$ & $E(\mathbf{G P a})$ \\
\hline
\end{tabular}


Vol.41, No. 1. January 2022

\begin{tabular}{|c|c|c|c|c|}
\hline GFRP & 10 & 78.5 & 1048 & 61.6 \\
\hline Hybrid (S25\%, G75\%) & 10 & 78.5 & 920 & 65.7 \\
\hline Hybrid (S50\%, G50\%) & 10 & 78.5 & 923 & 72 \\
\hline Hybrid (S75\%, G25\%) & 10 & 78.5 & 1030 & 128 \\
\hline
\end{tabular}

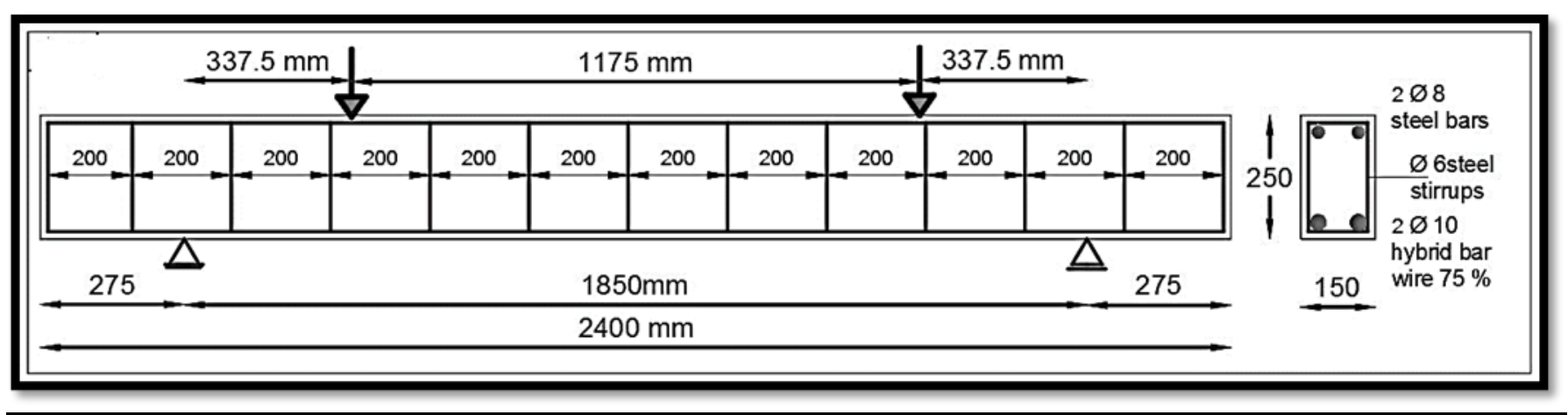

Fig.2. Details of beams.

\section{EXPERIMENTAL RESULTS AND DISCUSSION}

\subsection{Crack pattern and mode of failure:}

Initiation and spreading of cracks for different tested beams were observed visually and with magnifying glass. For all beams, it was noticed that the cracks in the both sides of the studied beams were approximately similar.

In group (1) The wider and deeper cracks which appeared in this beam Due to the relatively low modulus of elasticity of FRP bars, deeper cracks decrease the contribution of shear strength from uncracked concrete due to the lower depth of concrete in compression. Wider cracks decrease the contributions from the aggregated interlock and residual tensile strength. The mode of failure of D0 was flexural- shear failure but for D1 it was sudden shear failure without warning. The number of cracks for D1 at failure was noticed to be fewer than that in beam D0 which is reinforced with steel bars. The widespread of cracks was noticed on the beams, the cracks height and width in the beam of GFRP were more than the beam with steel due to the low modulus of elasticity of GFRP bars than the steel bars.

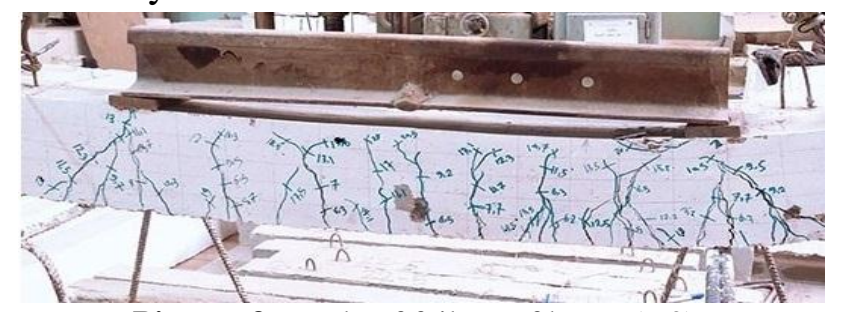

Picture.3. Mode of failure of beam (D0).

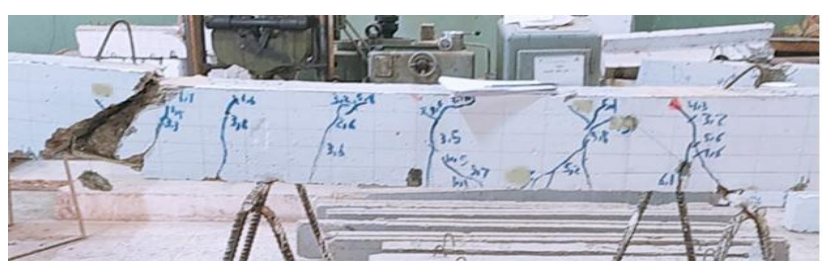

Picture.4. Mode of failure of beam (D1).

In group 2, The depth and width of the cracks in hybrid beams were smaller and shallower than the reference GFRP beam; this is due to the enhancement of GFRP by adding steel wires in the bar. The neutral axis should be lower than that in GFRP, the contribution to shear strength from uncracked concrete increases than GFRP due to the little increase in depth of concrete in compression due to the steel wires addition. And the smaller width of the cracks than GFRP bars increase the contributions from the aggregated interlock and 
residual tensile strength a little. Furthermore, using these new bars enhance the contributions of dowel action a little also. Therefore, the shear capacity of concrete beams reinforced with hybrid wires bars is better than that of the ones reinforced with GFRP bars, and it is as close as possible to steel beams in the behavior without corrosion.

Finally, it was noticed that D2 the flexural failure occurred in this beam with rupture in the reinforcement bars in the tension zone. In the beam D3 the shear failure with rupture in the reinforcement bars in the tension zone occurred. And in the beam D4 the shear failure with a high voice and rupture in the reinforcement bars and the failure was done in two places in the beam and there were a lot of previous warnings in high ultimate shear load as shown in Picture (5, 6 and 7).

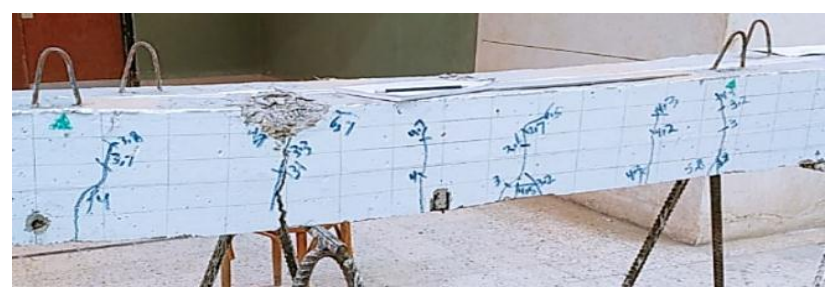

Picture.5. Mode of failure of beam (D2).

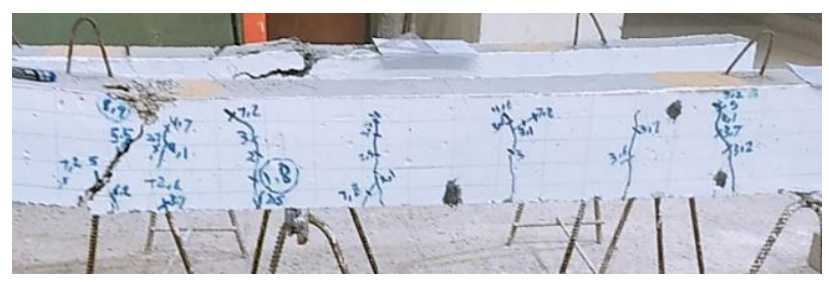

Picture.6. Mode of failure of beam (D3).

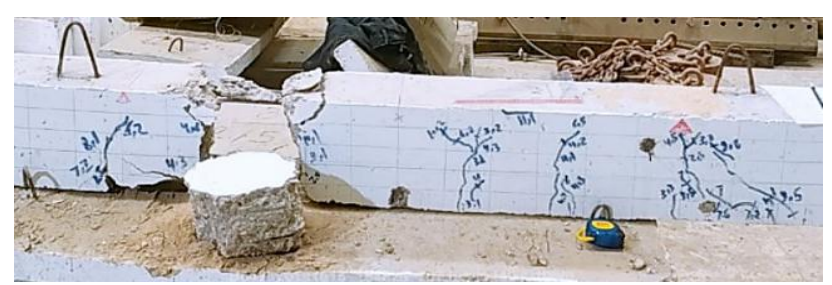

Picture.7. Mode of failure of beam (D4).

In group 3, which consisted of D5, D6 and D7 were shown in Picture (8,9 and 10). The cracks were first initiated at the bottom fiber of the beam in the constant moment zone. As the load increased, new cracks were created along the beam and the formed cracks propagated towards the point of load application. The rate of cracks propagation in this group was smaller than the reference beam D4 due to adding dosages of steel fibers in these beams. A major improvement in cracking pattern, small discrete cracks were formed and the rate of extension and propagation of these cracks were very slow than that when only steel stirrups were used. When the steel fibers incorporated with steel stirrups, the mode of failure changed from sudden and brittle diagonal tension failure accompanied with reinforcement rupture to more ductile diagonal tension failure. The steel fibers improved the confinement stress around the reinforcing bars and increased the tensile strength of concrete and reduced the splitting. The width of the major crack in the beam D7 with $1.2 \%$ steel fibers content was smaller than which in beams D6 and D5 with $0.8 \%$ and $0.4 \%$ respectively, and all of them were smaller than the corresponding reference beam D4. This decrease in crack width led to an increase in the number of cracks. This is due to bridging effects provided by steel fibers and better blocked action with surrounded concrete provided by steel stirrups which enabled better transmission of shear stress through the aggregate interlock. All that results in less brittle shear failures with high ultimate tensile strength and improved ductility. During the testing of the beam D6, the applied load reached to about $75 \%$ of the failure load and continued in increasing without any propagations or formation of other cracks till failure. This probably due to the random distribution of steel fiber in three dimensions over beam sections provided a closer spacing than reinforcing bars. After cracking, steel fibers bridged the crack in all directions. As a 
result, this reduced crack propagation of beams. Stress can be transferred across a crack through the bond between steel fiber and concrete along the surfaces of the steel fiber.

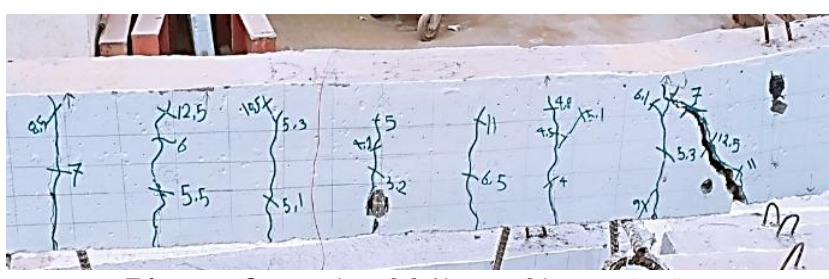

Picture.8. Mode of failure of beam (D5).

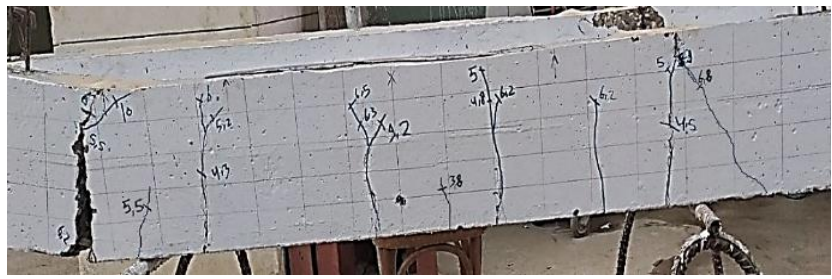

Picture.9. Mode of failure of beam (D6).

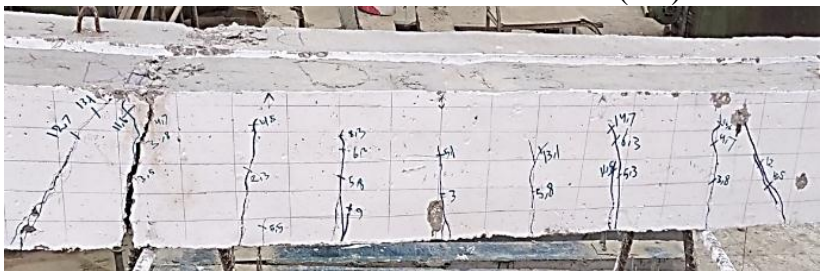

Picture.10. Mode of failure of beam (D7).

Table 7. Results of tested beams.

\begin{tabular}{|c|c|c|c|c|c|c|c|c|c|}
\hline \multirow[b]{2}{*}{ Group } & \multirow[b]{2}{*}{$\begin{array}{c}\text { Beam } \\
\text { No. }\end{array}$} & \multicolumn{7}{|c|}{ Experimental observations } & \multirow[b]{2}{*}{$\begin{array}{c}\text { Mode of } \\
\text { Failure }\end{array}$} \\
\hline & & $\begin{array}{c}P_{c r} \\
(t o n)\end{array}$ & $\begin{array}{c}P_{u} \\
(t o n)\end{array}$ & $\begin{array}{c}V_{c r} \\
(t o n)\end{array}$ & $\begin{array}{c}V_{u} \\
(\text { ton })\end{array}$ & $\begin{array}{r}\Delta_{\max } \\
(\mathrm{mm})\end{array}$ & $\begin{array}{c}\Delta_{c r} \\
(\mathbf{m m})\end{array}$ & $\begin{array}{c}\mu_{D} \\
\left(\Delta_{\max } / \Delta_{c r}\right)\end{array}$ & \\
\hline \multirow[b]{2}{*}{1} & D0 & 5 & 15 & 6.3 & 7.5 & 32 & 8 & 4.2 & F.S \\
\hline & D1 & 2.5 & 10.3 & 3.2 & 5.15 & 40.52 & 7.9 & 5.15 & S.F \\
\hline \multirow{3}{*}{2} & $\mathrm{D} 2$ & 2.6 & 6.75 & 3 & 3.375 & 35.4 & 16 & 2.2125 & F.F \\
\hline & D3 & 3.5 & 8.7 & 3.5 & 4.35 & 30.2 & 10.4 & 2.9 & S.F \\
\hline & D4 & 2.5 & 11.1 & 4.6 & 5.55 & 28.3 & 7 & 4 & F.F and B.F \\
\hline \multirow{3}{*}{3} & D5 & 3 & 11.25 & 5.3 & 5.625 & 28.9 & 6.8 & 4.25 & S.F \\
\hline & D6 & 2 & 13.6 & 4.5 & 6.8 & 30 & 4.2 & 7.14 & S.F \\
\hline & D7 & 2.3 & 14.8 & 4.7 & 7.4 & 34.1 & 4 & 8.5 & S.F \\
\hline
\end{tabular}

Where $\mathrm{P}_{\text {cr }}$ is the load at the first flexural crack, $\mathrm{P}_{\mathrm{u}}$ is the load at ultimate failure, $\mathrm{V}_{\mathrm{cr}}$ is the load at first major diagonal crack and $\mathrm{V}_{\mathrm{u}}$ is the ultimate shear load, $\Delta_{\max }$ is the maximum deflection, $\Delta_{c r}$ is the deflection at the first crack, $\boldsymbol{\mu}_{D}=$ the displacement ductility index.

* S.F = Shear Failure, F. F = flexure failure, F.S = Flexure- Shear failure, and B.F = Bond failure

\subsection{Mid span deflection:}

The relation between the applied load and the measured mid-span deflection was illustrated from Fig (3) to Fig (5). Ductility of reinforced concrete beams can be measured based on measured values of the mid-span deflection at cracking and at that failure as shown in Table (7). In the group (1), the type of main reinforcement Playes an important role in effecting mid- span deflection of the beams. That is due to the dowel action phenomena which affectes the stiffness of the bars and the modulus of elasticity. From the Fig (3) it was noticed that, at any level of loading, the deflection of the glass fiber reinforced polymer beam D1 is higher than that of the hybrid-wires 
beam D4 and the steel beam D0, because the modulus of elasticity of the steel bars is higher than hybrid wires bars and Gfrp bars.

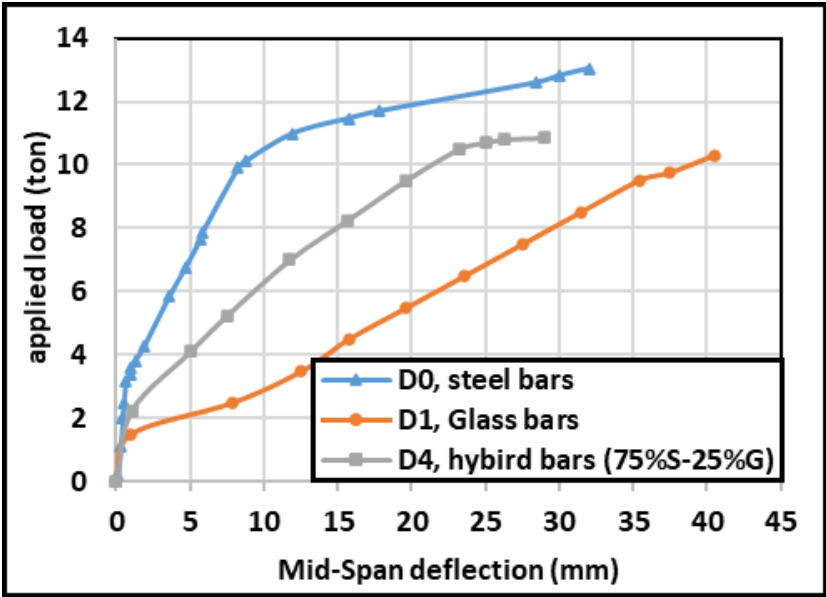

Fig.3. Load-deflection relationships of beams in group (1).

The applied load was plotted against the measured mid- span deflection of tested beams of group 2. It was clear from these Figs that, after cracking stage, whenever the steel wires ratio to the Gfrp ratio in the bar increases, the mid span deflection decreases. Therefore, the beam D4 is the smallest value in a mid-span deflection with a high ratio of steel wires in hybrid-wire bars. This was noticed because of the low modulus of elasticity of glass fiber compared to the steel wires.

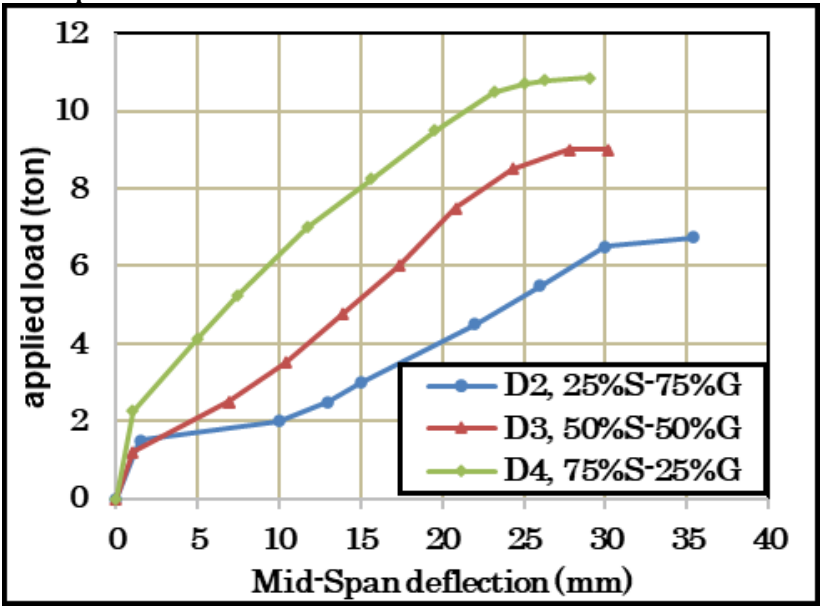

Fig.4. Load-deflection relationships of beams in group (2). In group 3, the shear load versus mid - span deflection were figured in Fig (5). The shear load deflection in these series exhibited similar characteristics. For all beams, the shear load deflection relationship is bilinear in the first part up to flexural cracking appearance. The second part, post-cracking up to failure, represents the cracked beam with reduced moment of inertia. For beams D5, 6 and D7, the addition of steel fibers to concrete in presence of minimum value of steel stirrups ( $\Phi 6$ @ 200mm) not only enhances the shear capacity but also improves the deformation characteristics. This improvement is evident when the ratio of steel fibers volume increases from $0.4 \%$ to $1.2 \%$. this due to the enhancement of tension strength of concrete and the axial stiffness of the longitudinal hybrid- wires bars may be also enhanced. The increase in steel fibers volume $\left(V_{f} \%\right)$ from zero to $1.2 \%$ leads to decrease the central deflection measured for all of the tested beams. the high shear strength of the tested beams compared to the small flexural strength governes by the small amount of hybrid bars is hindered the full utilization of additional steel fiber.

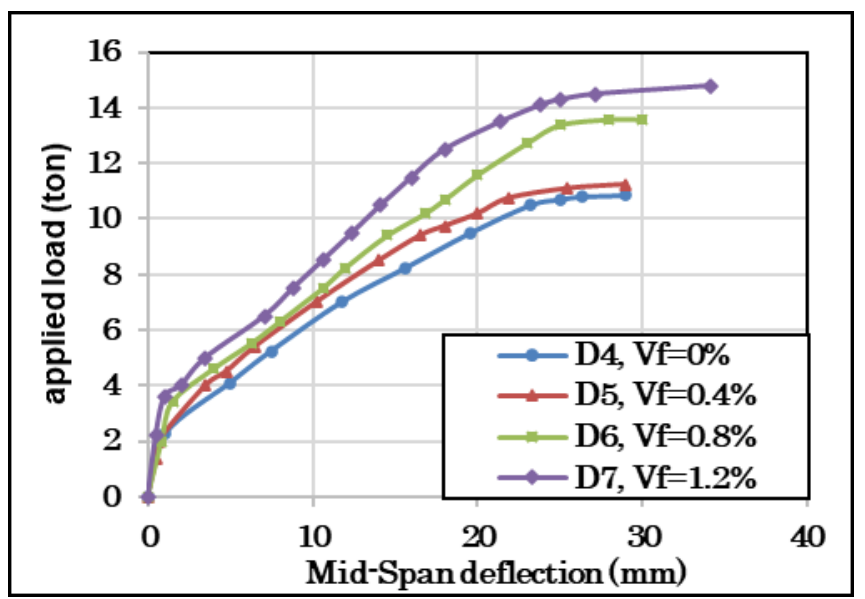

Fig.5. Load-deflection relationships of beams in group (3).

\section{3. ultimate load capacity:}

The effects of type of main reinforcement on ultimate shear capacity Vult of beams in the group (1) was shown in Table 5 and Fig 6. It was noticed that, the beam D0 reinforced with steel bars as a main reinforcement has the ultimate load higher than the beam D4 reinforced with the hybrid wires reinforcement bars and both of them higher than beam D1 which is reinforced with glass fiber reinforcement bars. 


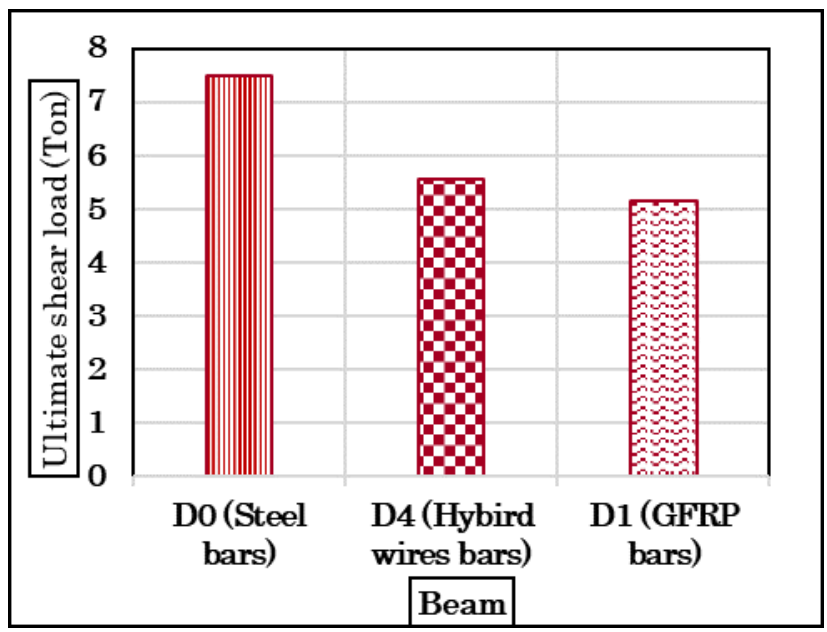

Fig.6. Effect of type of reinforcement on ultimate shear capacity $(\mathrm{Vu})$.

In group 2, It was noticed that the increase of steel wires area in the bar to $75 \%$ of the total area increases the ultimate shear strength by $64 \%$ compared to that reinforced with the hybrid bars $25 \%$ steel wires area. This increase in shear strength is due to improvement in the shear transfer mechanisms. Increasing the ratio of steel wires in hybrid bars increases the uncracked concrete compression zone and increases the contributions from aggregated interlock and residual tensile strength. In addition, increasing the steel wires ratio in the bar increases the dowel capacity of the member due to the modulus of elasticity as shown in Fig (7).

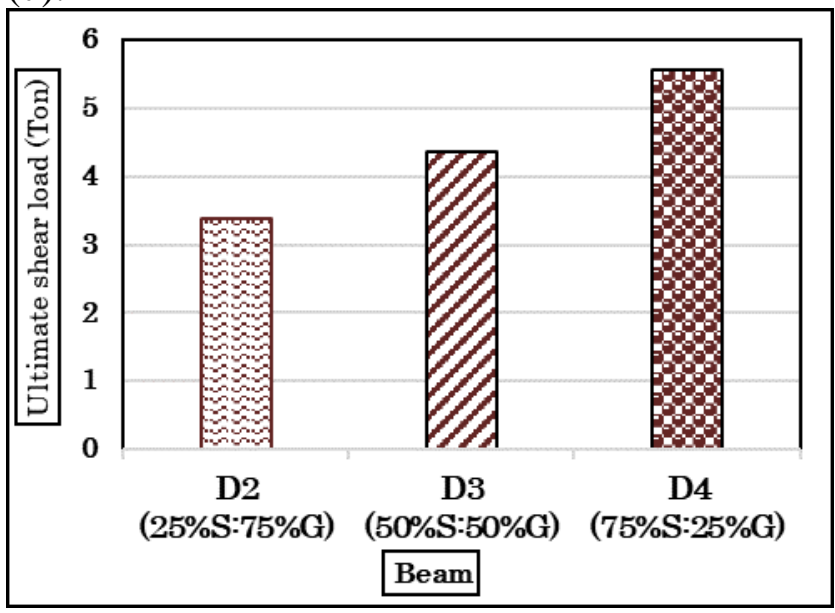

Fig.7. Effect of (Steel wires-to-GFRP) ratio changing. In group 3, it was noticed that increasing steel fibers volume from zero to $1.2 \%$ volume fraction leads to improve in shear capacity by approximately $30 \%$ as shown in Fig (8).

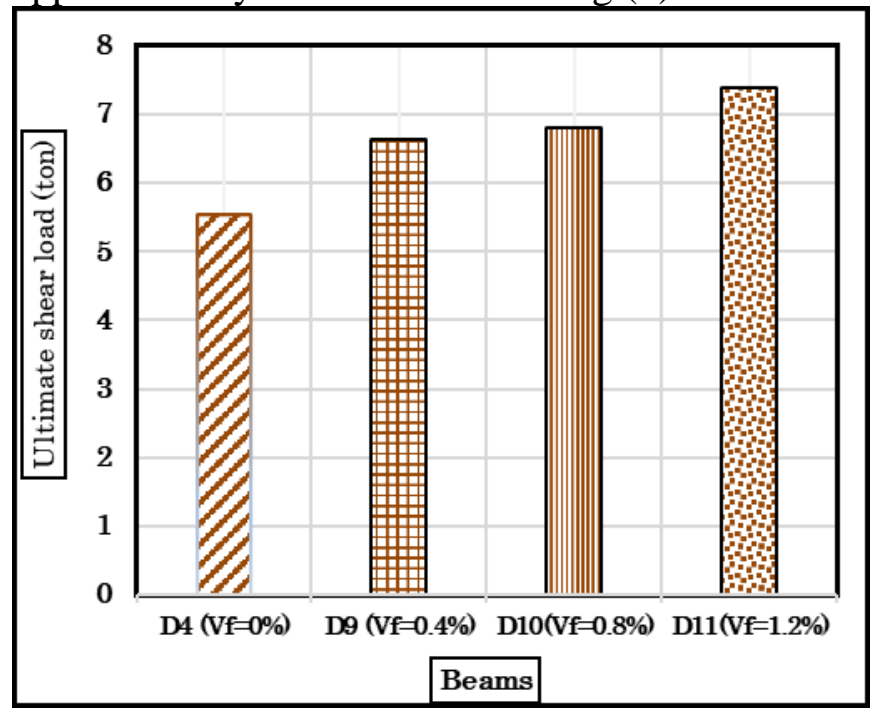

Fig.8. Effect of (Steel fibers volume ratio) on the ultimate shear capacity.

4. Comparison BetWeEN THEORETICAL AND EXPERIMENTAL RESULTS FOR BEAMS

The shear strength of the tested beams reinforced with hybrid-wires bars as main reinforcement with steel stirrups or vertical hybrid wires bars as web reinforcement was predicted using some available empirical methods found in the different codes and guidelines for FRP reinforced concrete members. These codes include the ACI 440. IR06 [19], ISIS 2007[17], JSCE 1997 [20], CSA S806-02 [16], CNR 2006 [17], and finally theBISE-1999[58]. Most of the available design codes formulae give a considerable closer value of ultimate shear capacity for beams with steel stirrups compared with those obtained from the experimental test results as shown in Table(8).CSA S806-02 [16] and ISIS 2007[17] give slightly underestimating values and are considered to be the nearest values to the corresponding experimental values obtained through this work. The second arrangement of the underestimating value of $\left(V_{p r e} / V_{\text {exp }}\right)$ is by BISE guideline[18] .In the latter arrangement, ACI code[19] is considered the lowest and more conservative than all codes. 
Vol.41, No. 1. January 2022

Table.8. Predicted and experimental shear capacity for hybrid-wire beams with steel stirrups as web reinforcement.

\begin{tabular}{|c|c|c|c|c|c|c|c|c|c|c|c|c|c|}
\hline \multirow[b]{2}{*}{$\begin{array}{c}\text { Beam } \\
\text { N0. }\end{array}$} & \multirow[b]{2}{*}{$\begin{array}{c}V_{U} \\
(\exp ) \\
\text { Ton. }\end{array}$} & \multicolumn{6}{|c|}{$V_{U}$ (pre) Ton. } & \multicolumn{3}{|c|}{$V_{U}($ exp/pre $)$} & \multirow[b]{2}{*}{ CSA } & \multirow[b]{2}{*}{ BISE } & \multirow[b]{2}{*}{$\mathrm{CNR}$} \\
\hline & & $\begin{array}{r}\text { ACI } \\
440- \\
06\end{array}$ & ISIS & JSCE & CSA & BISE & CNR & $\begin{array}{r}\text { ACI } \\
440- \\
06\end{array}$ & ISIS & JSCE & & & \\
\hline D1 & 5.15 & 28.74 & 36.45 & 32.42 & 38.08 & 35.91 & 34.20 & 0.87 & 1.10 & 0.98 & 1.15 & 1.09 & 1.04 \\
\hline D2 & 3.375 & 29.01 & 37.00 & 32.69 & 38.48 & 36.26 & 34.67 & 0.86 & 1.10 & 0.97 & 1.14 & 1.07 & 1.03 \\
\hline D3 & 4.35 & 29.41 & 37.81 & 33.09 & 39.05 & 36.77 & 35.38 & 0.67 & 0.86 & 0.76 & 0.89 & 0.84 & 0.81 \\
\hline D4 & 5.55 & 32.27 & 43.85 & 35.89 & 43.10 & 40.34 & 40.60 & 0.57 & 0.78 & 0.64 & 0.77 & 0.72 & 0.72 \\
\hline \multicolumn{8}{|c|}{ Averge } & 0.74 & 0.96 & 0.84 & 0.98 & 0.93 & 0.9 \\
\hline
\end{tabular}

Comparison of the experimental results with those estimated using Wafa and Ashour [23], Shin et al. [22], and the method proposed by R. Narayanan [24] for normal strength steel fibers concrete beams with stirrups are shown in Table (10). From the Table, the steel fiber ratio significantly effects the both experimental and predicted shear carrying capacity. Ashour gives underestimating values of ultimate shear capacity while Shin and R. Narayanan give overestimating values of ultimate shear capacity. However, Ashour gives a suitable equation which can be used to predict the ultimate shear strength of steel fibers concrete beams reinforced with hybrid wires bars with steel stirrups. Some of These proposed formulas and code guidelines are summarized in Table 9 .

\begin{tabular}{|c|c|c|}
\hline $\begin{array}{l}\text { Investigato } \\
\mathrm{r}\end{array}$ & Predictive equation for ultimate shear strength [MPa] & $\begin{array}{l}\text { Applicatio } \\
n\end{array}$ \\
\hline $\begin{array}{c}\text { Shin et al } \\
{[35]}\end{array}$ & $v_{u}=0.22 f_{s p t}+217 \rho\left[\frac{d}{a}\right]+0.34 \tau F \quad\left(M P_{a}\right)$ & \\
\hline $\begin{array}{c}\text { Mahmoud } \\
\text { A.IMAM } \\
{[36]}\end{array}$ & 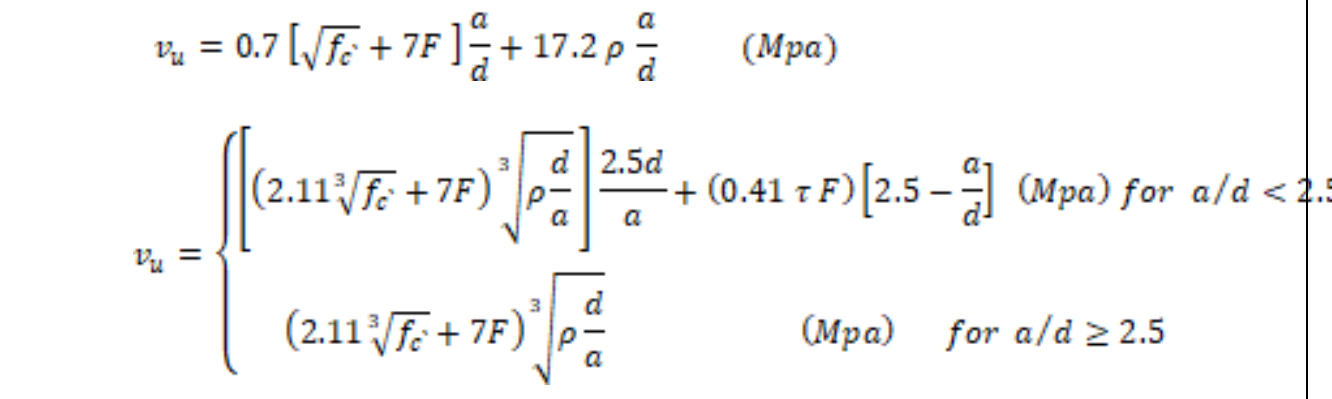 & $\begin{array}{l}5 \text { Beams } \\
\text { with steel } \\
\text { fibers }\end{array}$ \\
\hline $\begin{array}{c}\text { Narayanan } \\
\text { et al } \\
\text { [12] }\end{array}$ & $\begin{array}{l}v_{u}=e\left[0.24 f_{s p t}+80 \rho\left[\frac{d}{a}\right]\right]+0.41 \tau F \\
e=2.8 \frac{d}{a} \quad \text { for } a / d \subseteq 2.8\end{array}$ & \\
\hline
\end{tabular}


Table. 10. Comparison Between Theoretical and Experimental Results for beams longitudinally reinforced with hybridwires bars, steel stirrups and steel fibers

\begin{tabular}{|c|c|c|c|c|c|c|c|}
\hline \multirow{2}{*}{$\begin{array}{c}\text { Beam } \\
\text { N0. }\end{array}$} & $\begin{array}{c}V_{U} \\
(\text { exp }) \\
\text { Ton. }\end{array}$ & \multicolumn{3}{|c|}{$V_{U}($ pre $)$ Ton. } & \multicolumn{3}{c|}{$V_{U}($ exp/pre) } \\
\cline { 3 - 8 } & Shin & Imam & Narayanan & Ashour & Shin & Narayanan \\
\hline D5 & 5.625 & 41.56 & 90.75 & 72 & 0.74 & 1.5 & 1.28 \\
\hline D6 & 6.8 & 58.97 & 94.57 & 75.9 & 0.87 & 1.3 & 1.11 \\
\hline D7 & 7.4 & 76.24 & 98.35 & 80.5 & 1.03 & 1.32 & 1.08 \\
\hline \multicolumn{3}{|c|}{ Averge } & 0.88 & 1.37 & 1.15 \\
\hline
\end{tabular}

\section{CONCLUSION}

The following points have been concluded:

1. The hybrid-wire bars have a modulus of elasticity larger than that of the GFRP bars and less than that of steel bars.

2. A higher value of shear strength is obtained when the ratio is increased to reach $75 \%$, and it can be used as main reinforcment instead of steel reinforcement.

3. By increasing the ratio of steel wires to (GFRP) in the reinforcement bar (ASteel/ Atotal) as main reinforcement from $25 \%$ to $75 \%$ the defection decreases due to the high modulus of elasticity of steel wires. And the ultimate shear capacity increases by approximately

$64 \%$.

4. By using $1.2 \%$ steel fibers by volume incorporated with minimum steel stirrups, the mode of failure changes from catastrophic and brittle diagonal tension failure accompanied with reinforcement rupture to more ductile diagonal tension failure. The steel fibers improve the confinement stress around the reinforcing bars. increase the tensile strength of concrete and reduce the splitting. Also, increasing the steel fibers ratio leads to increase the ultimate shear load.
5. Confirming that $1.2 \%$ of steel fibers can replace a part of steel stirrups which reaches moderately higher shear stresses at failure and improves crack propagation resistance and shows higher ductility at failure in case of beams reinforced with hybrid wires bars.

\section{REFERENCE}

[1] Awadallah ZH, Ahmedmm, Farghal OA, Fahmy MFJJoES. Some Parameters Affecting Shear Behavior of High Strength Fiber Reinforced Concrete Beams Longitudinally Reinforced with BFRP Rebars, Journal of Engineering, Vol (42),1163-78. 2014

[2] Yinghao L, Yong YJCPBE. Arrangement of hybrid rebars on flexural behavior of HSC beams, Composites Part B: Engineering, Vol (45).22-31. 2013

[3] Saikia B, Thomas J, Ramaswamy A, Rao KN. Performance of hybrid rebars as longitudinal reinforcement in normal strength concrete, Materials and structures, Vol (38),857-64. 2005

[4] Seo D-W, Park K-T, You Y-J, Kim H-YJE. Enhancement in elastic modulus of GFRP bars by material hybridization, Scientific research, Vol (5),865-9. 2013

[5] Seo D-W, Park K-T, You Y-J, Lee SY. Experimental investigation for tensile 
performance of GFRP-steel hybridized rebar, Advances in Materials Science and Engineering, Vol (2016). 9401427.2016

[6] Ashour SA, Hasanain GS, Wafa FFJSJ. Shear behavior of high-strength fiber reinforced concrete beams ACI Structural journal, 89, 176-184.1992.

[7] Kamura Ari, Tefaruk Haktanir and Faith Altun Effect of steel fibre addition on mechanical properties of concrete and RC beams. Construction and building materials, 1.21, 654-661. 2006.

[8] Soon-Ho Cho and Yoon-IL Kim Effects of steel fibres on short beams loaded in shear. ACI structural journal, 100, 765-774. 2003.

[9] Amir A, Mirsayah and Nemkumar Banthia Shear strength of steel fibre reinforced concrete. ACI Material journal, 99, 473-479. 2002.

[10] Robert J Frosch, Behaviour of Large Scale Reinforced Concrete Beams with Minimum Shear Reinforcement. ACI Structural journal, 97, 814- 820. 2000.

[11] T Muller, K. Hoschemacher and Y. Ribakov Effect of steel fibres on mechanical properties of high strength concrete. Materials and design, 1-12. 2009.

[12] Yoon Keun Kwak, Marc O Eberhard, Woo-Suk Kim, and Jubum Kim. Shear Strength Of Steel FiberReinforced Concrete Beams without stirrups. ACI Structural journal. 99, 530538. 2008.

[13] Jumaa GB, Yousif AR. Size effect in shear failure of high strength concrete beams without stirrup, reinforced with basalt FRP bars, KSCE Journal of Civil Engineering, Vol (23),1636-50.2019.

[14] Yoo D-Y, Yang J-M. Effects of stirrup, steel fiber, and beam size on shear behavior of high-strength concrete beams, Cement and Concrete Composites, Vol (87),137-48. 2018.

[15] ECP 208," Egyptian Code of Practice for the Use of Fiber Reinforced Polymers (FRP) in the Construction Fields, Egyptian Standing Code Committee for the Use of Fiber Reinforced Polymers in the Construction Fields, Ministry of Housing, Utilities Urban Utilities, Egypt.2005.

[16] Canadian Standards Association. Design and construction of building components with fibre-reinforced polymers. Canadian Standards Association; 2002. Bars Under Static Loads, 2019

[17] Mufti AA, ISIS Canada. A Canadian Network of Centres of Excellence, "Reinforcing Concrete Structures with Fibre-Reinforced Polymers," 2006.

[18] B.I.O.S. Engineers, Interim guidance on the design of reinforced concrete structures using fiber composite reinforcement.," IStructE, SETO Ltd., London., (BISE-1999).

[19] American Concrete Institute. Committee 440. Guide for the Design and Construction of Concrete Reinforced with FRP Bars: ACI 440.1 R-03. American Concrete Institute. 2015

[20] Japan Society of Civil Engineers (JSCE-1997). "Recommendation for design and construction of concrete structures using continuous fiber reinforcing materials." Concrete 
engineering series 23, A. Machida, ed., Japan Society of Civil Engineers, Tokyo.

[21] National Research Council (CNRDT 203/2006). "Guide for the Design and Construction of Concrete Structures Reinforced with Fiber-Reinforced Polymer Bars", Rome, Italy, 2006.

[22] Shin S W, Oh and Ghosh S K Shear behavior of laboratory sized High Strength concrete beams reinforced with bars and steel fibres. ACI special publication, Vol(142), 181-200. 1994.
[23] Wafa FF, Ashour SA. Mechanical properties of high-strength fiber reinforced concrete. Materials Journal. Vol (89),449-55. 1992.

[24] Narayanan R, Darwish IY. Use of steel fibers as shear reinforcement. Structural Journal, Vol (84),21627.1987. 


\section{تحسين سلوك القص للكمرات المسلحة بالأسياخ المهجنة باستخدم الألياف الفولاذية}

الملخص: التحدي الرئيسي للمهندسين المدنيين هو توفير مواد البناء المستدامة والصديقة للبيئة والاقتصادية. العثور على مواد بناء جديدة

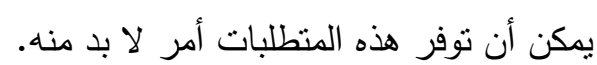
يدرس هذا البحث سلوك القص للكمرات الخرسانية المسلحة باسياخ هجينة بأقل عدد من الكانات. تم اختبار ثمانية كمرات معرضة لقوى القص تم تقسيم البحث إلى ثلاث مجموعات وفق للعوامل التالية:

$$
\text { - نوع التسليح الرئيسي (اسياخ حديدية ، اسياخ من الألياف الزجاجية ، اسياخ أسلاك هجينة). }
$$

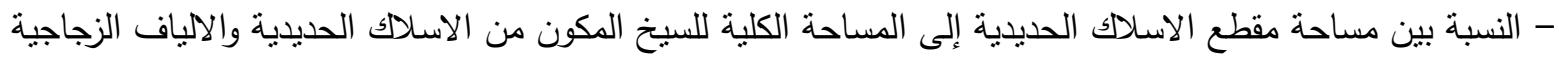

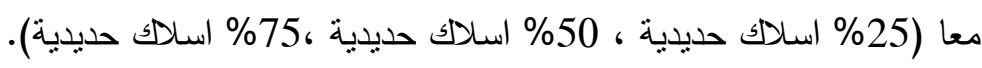

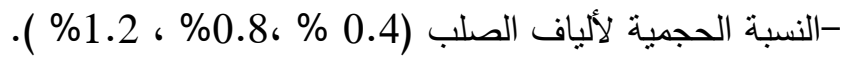
أظهرت نتائج الاختبارات المعملية أن استخدام أسياخ الهجينة كتعزيز رئيسي للتغلب على المعامل المنخفض لمرونة اسياخ الالياف البوليمرية الزجاجية أدى إلى تحسين سلوك التشريخ وقوة القص ومنانة الكمرات المختبرة ، ونقل نمط الانهيار للكمرات الى نمط اكثر متانة من الكمرات المسلحة بالياف الزجاج.من المهم ملاحظة أن زيادة نسبة أسلاكى

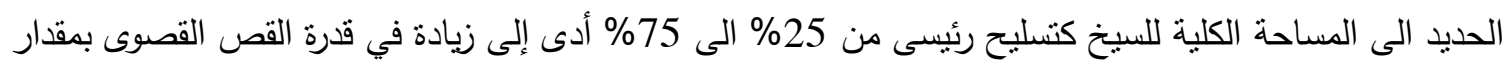

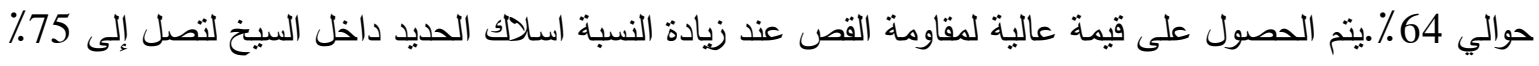

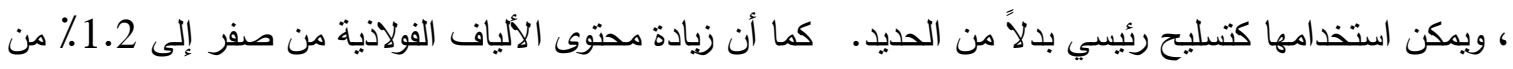

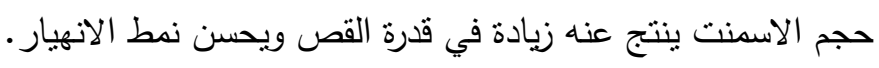

